\title{
Innovative Solutions in Mine Detection
}

\author{
DOI 10.17047/Hadtud.2020.30.E.198
}

\begin{abstract}
:
Detecting mines and other explosive devices left behind in mined areas and marking their location accurately is key to making the area safe. The development of innovative technologies and techniques to this is highly important. By using biological-based reconnaissance, the technical tools previously applied to the task can be replaced, or by using the two methods together, better detection efficiency can be achieved. To understand these biological systems offers unique opportunities to develop new capabilities. Biologicalbased detection methods are expected to make a significant contribution to the development of mine detection methods. In this study, I present the capabilities and application possibilities of animals that can be used effectively as part of this process.
\end{abstract}

\section{Keywords:}

mine, mine detection, demining, search, animals

\section{Innovatív megoldások az aknafelderítésben}

\begin{abstract}
Absztrakt:
Az aknásított területeken hátrahagyott aknák és egyéb robbanóanyagot tartalmazó eszközök felkutatása, elhelyekedésük pontos megjelölése kulcsfontosságú a terület biztonságossá tétele végett. $A z$ ennek érdekében alkalmazható innovatív technológiák és technikák kidolgozása kiemelten fontos. A biológiai alapú felderítéssel a feladatra korábban alkalmazott technikai eszközök kiválthatóak, vagy a két módszer együttes alkalmazásával jobb előtalálási hatékonyság érhető el. Ezáltal a biológiai rendszerek megértése egyedülálló lehetőségeket kínál az új képességek fejlesztésére. Várható, hogy a biológiai alapú felderítő módszerek jelentősen hozzájárulnak az aknafelderítés módszereinek fejlődéséhez. A tanulmányban azon állatok képességeit és alkalmazási lehetőségeit mutatom be, melyek e folyamat részeként hatékonyan alkalmazhatóak.
\end{abstract}

Kulcsszavak:

akna, aknafelderítés, aknamentesítés, kutatás, állatok

\section{Introduction}

Throughout the modern history of mankind, the use of landmines has been favoured. After the end of military conflicts, landmines have remained in the area, making postconflict resumption and sustainable development difficult or impossible. Landmines and other explosive remains of war (ERW), unexploded ordnances (UXO) pose a

\footnotetext{
National University of Public Service, Doctoral School of Military Sciences; e-mail: szataizsolt@gmail.com; https://orcid.org/0000-0001-6963-0500
} 
direct threat to the safety of the civilian population. ${ }^{2}$ These devices have taken more than 130,000 victims worldwide in the last 20 years. ${ }^{3}$

Cleaning up these areas is a major challenge for both local forces and international organisations. After all, over time, landmines may become increasingly insecure and the mine contaminated areas will become increasingly inaccessible. ${ }^{4}$

Nevertheless, landmine detection is an extremely complex and costly activity. In many cases, due to the high cost, most modern landmine or explosive detection tools are unavailable, while classic demining activities are time consuming and extremely dangerous, so there is a need to develop and apply innovative solutions in the field. In line with the declaration of the 2018 NATO Summit in Brussels, NATO's Science for Peace and Security program will continue to support scientific and technological developments in the field of mine detection, including a strong emphasis on the development of new capabilities and technologies.

The aim of humanitarian demining is to detect and destroy landmines as safely as possible and in the most non-invasive way with environmental considerations in mind.

The quality of landmine detection has a direct impact on the effectiveness of this process. Most of the available methods for detecting landmines are limited by their sensitivity and operational complexity. Landmines that have been in the soil for a long time not only carry the hazards associated with their intended operation, but over time, explosives begin to leak from the buried landmines, which can also be found in the surrounding soil and vegetation.

This level of soil contamination is a matter of serious concern, as the dissolution of explosives can contaminate the drinking water supply of the soil and in the long run it would cause serious environmental damage.

\section{Biological landmine detection}

Since World War II, the principles of landmine detection have not much changed. Today, classic demining kits are very similar to the tools used more than 70 years ago. However, the possible methods of mine detection can be defined in an extremely wide range.

The method used for detecting and demining depends on the resources available, the training of personnel and their level of training. Taking all this into account, landmine and UXO detection methods can be categorised based on a variety of criteria. However, it can be established that mine detection is in all cases based on the detection of either the explosive device or the explosive evaporating from it.

\footnotetext{
${ }^{2}$ Horváth 2018. p. 68.

${ }^{3}$ Landmine Monitor Report 2019. p. 55.

${ }^{4}$ Szatai 2019. p. 46.
} 
A landmine after laying in its place, gradually releases explosive derivatives into the surrounding soil. While in general approximately $95 \%$ of the released explosive is absorbed to the surrounding soil, the remaining $5 \%$ is eliminated mainly by dissolution in water in the pores of the soil, much of which reaches the surface in the form of steam, so that they can be detected by appropriate methods. One of the key issues in the detection of explosive vapours and residues is that the sensor must be able to operate at a very low detection threshold, because the available explosive concentration is extremely low. Trinitrotoluene (TNT) is one of the most common explosives used in landmines alone or as a component of other explosives. It occurs in about $80 \%$ of all landmines. ${ }^{5}$

Table 1.

Typical composition of some military high explosives

(Source: Created by the author, based on Macdonald et al. 2003. p. 201)

\begin{tabular}{|l|l|}
\hline \multicolumn{1}{|c|}{ Military explosive } & \multicolumn{1}{c|}{ Main composition } \\
\hline C-2 & RDX+TNT+DNT+NC+MNT \\
\hline C-3 & RDX+TNT+DNT+Tetryl+NC \\
\hline C-4 & RDX+ Polysobutylene+Fuel oil \\
\hline Cyclotol & RDX+TNT \\
\hline DBX & TNT+RDX+AN+AL \\
\hline HTA-1 & HMX+TNT+AL \\
\hline Pentolite & PETN+TNT \\
\hline PTX-1 & RDX+TNT+Tetryl \\
\hline PTX-2 & RDX+TNT+PETN \\
\hline Teryol & TNT+Tetryl \\
\hline
\end{tabular}

However, TNT-based explosives also contain other ingredients. Practical research shows that 2,4-dinitrotoluene (2,4-DNT), the by-product of TNT production, thus appears as an impurity in military-grade TNT, is the most commonly detected substance in near-ground explosive concentrations. The reason for this, that TNT is a readily biodegradable and very low vapour pressure material with a very short halflife in soil, approximately one day at $22{ }^{\circ} \mathrm{C}$. 2,4-DNT is also much less biodegradable and has a higher vapor pressure, accordingly, it is the most abundant material in the air layer above the landmines.

In experiments to detect these substances, in order to effectively detect the concentrations of 2,4-DNT and TNT in the air above the landmines, the detection systems must be able to detect $10^{-18} \mathrm{~g} / \mathrm{ml}$ in dry soil and $10^{-15} \mathrm{~g} / \mathrm{ml}$ in wet soil.

\footnotetext{
${ }^{5}$ Mine Detection Dogs 2003. p. 197.
} 


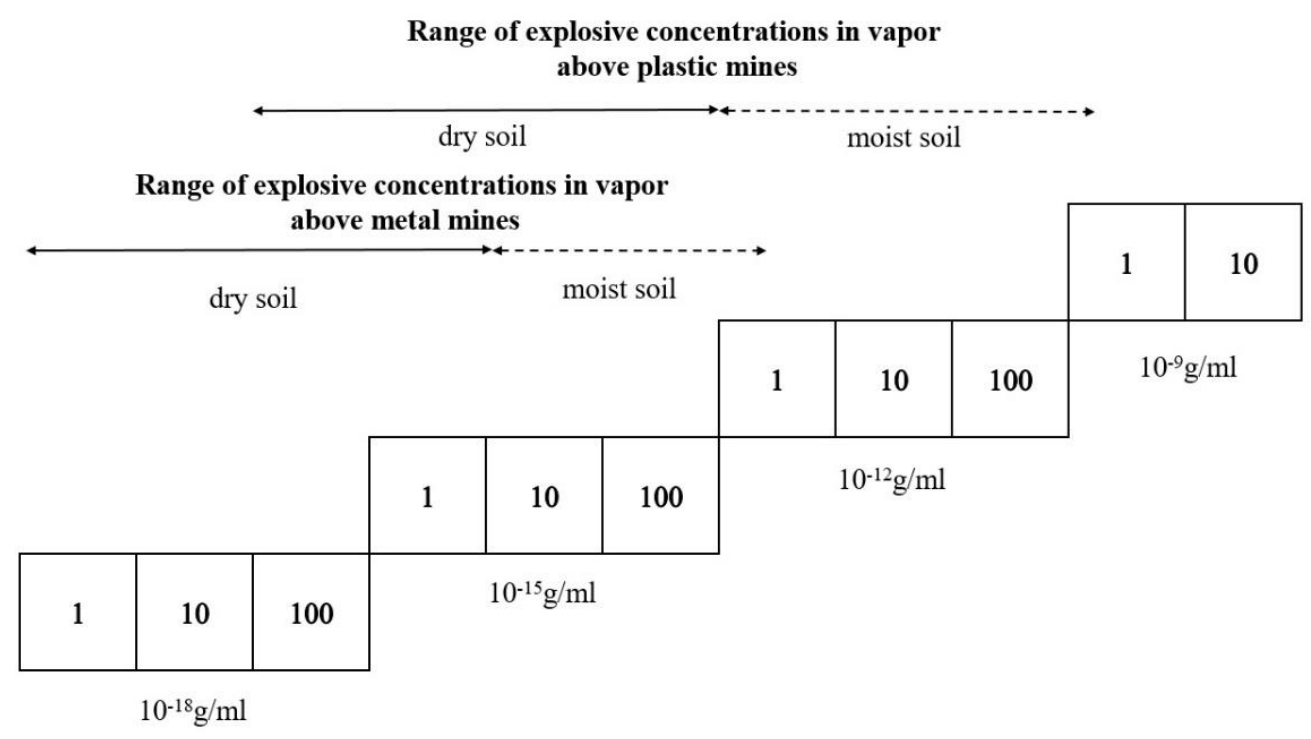

Figure 1.

Concentrations of 2,4 DNT and TNT near the soil above the landmines

(Source: Created by the author, based on Macdonald et al. 2003. p. 68.)

Based on studies, both biological and chemical sensors perform better when the soil moisture is high. ${ }^{6}$ The reason for this is, that water "competes" with TNT and DNT to bind to soil particles, while more TNT and DNT molecules are placed in certain layers of soil where they diffuse and higher concentrations of explosive molecules appear in the air layer above landmines. These physical and chemical processes provide the basis for the detectability of evaporation of explosives. Molecular evaporation of explosives can be detected by biological and chemical methods.

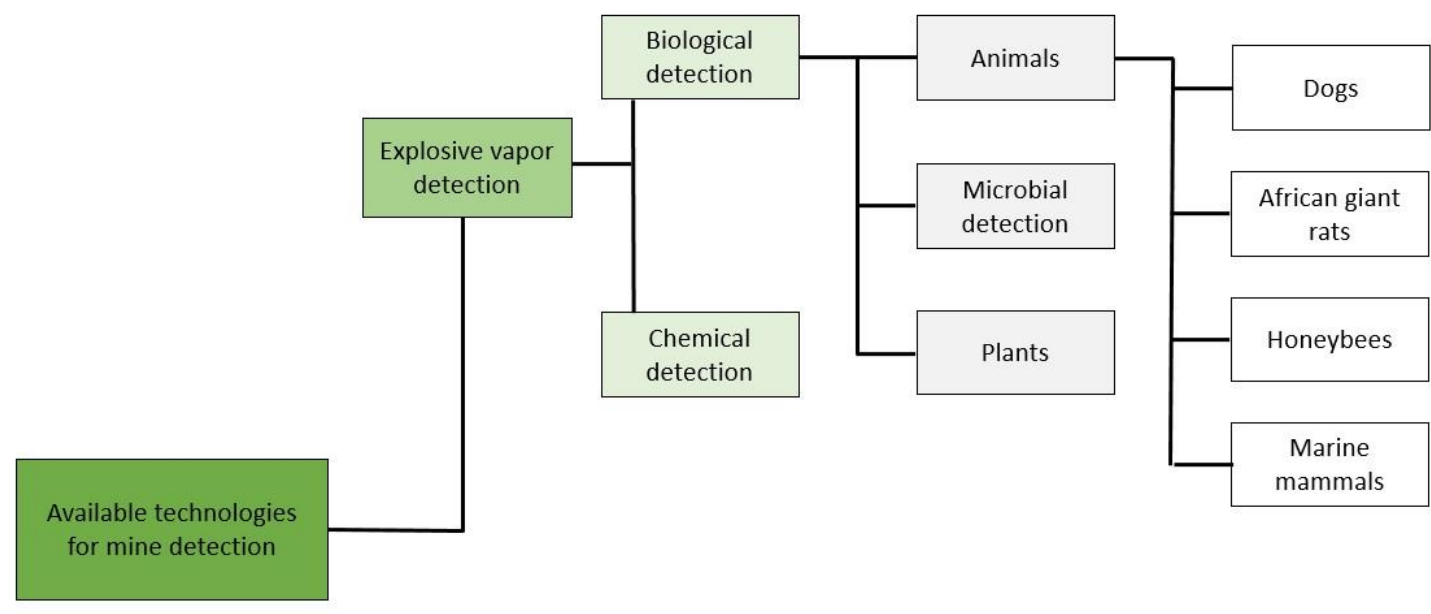

Figure 2.

Available biological technologies for mine detection

(Source: Created by the author)

\footnotetext{
${ }^{6}$ Existing and Potential Standoff Explosives Detection Techniques 2004. p. 63.
} 
The apply of methods based on chemical manners implies the utilize of technical devices based on different operating principles, with which evaporating explosive odor molecules can be detected at a given level of sensitivity. The biological method involves the use of plants, bacteria, and animals.

In this study, I present animal-supported mine detection methods in particular the innovative methods of biological detection. This means the use of animals whose abilities and characteristics make them suitable for the performance of professional tasks in this direction. ${ }^{7}$ The following animals are most commonly used for mine detection:
1) dogs;
2) african giant rats;
3) honey bees;
4) marine mammals.

\section{Utilization of mine detecting dogs}

During the interactions with mankind, both men and dogs underwent changes that were beneficial to both parties and they developed in co-evolution with each other. ${ }^{8}$ This was a relatively long-term, complex process in which individuals went through changes that have benefited humanity. In the process, man has selected individuals with beneficial traits and passed them on. One such beneficial property was the good smelling.

The smelling is a form of chemical perception and one of the oldest and most complex modes of detection. ${ }^{9}$ Smelling is based on chemical perception, so inhaled odors must have chemical properties in order to create the sence of smell. Human sense of smell is weaker and less developed than that of animals. ${ }^{10}$ During the evolutionary development, the dog's sense of smell has become more advanced than that of human, because dogs maintained proximity to the earth. The dog relies mostly on its nose to obtain certain informations about his environment merely by sniffing. The olfactory ability of dogs is a complex system that is difficult to be expressed in ratios. So much for sure, that the size of the olfactory mucosa is different in humans and dogs. Illustratively, all this means that the olfactory field of a German Shepherd dog, when spread out, corresponds a carpet with a size of $1.5 \times 1.5$ meter, while in humans this area is only the size of a matchbox. ${ }^{11}$ The dog's nose works on the principle of collecting and analyzing inhaled particles and molecules on this surprisingly large surface.

When a dog sniffs, the air flows into the nasal cavity. Each sniff contains five to seven tiny inhalations and exhalations of about 50 milliliters of air per second.

\footnotetext{
${ }^{7}$ Szatai 2019. p. 56.

${ }^{8}$ Miklósi 2010. p. 161.

${ }^{9}$ Vroon et al. 2005. p. 24.

${ }^{10}$ Bálint 1986. p. 1165.

${ }^{11}$ Fehér 1980. p. 724.
} 
The exhaled air is high in humidity and collects additional molecules outside the nasal cavity and since the same air is immediately re-sucked in, so are the odor molecules in the nose that are released by the increased humidity. ${ }^{12}$ Knowing this, it can be concluded that the physiological structure of the nose of the dogs is the explanation for their excellent ability to detect low odor concentrations. Smells can be sensitized and refined by dogs.

This is achieved by dogs by creating an air vortex in the nasal cavity. By creating a vortex of varying intensity, the nostrils dilate to achieve optimal airflow. This allows the odors to remain in contact with the olfactory mucosa for an extended period of time.

This allows you to constantly gather new information and clarify its nature or the exact location of the odor source. Utilizing these skills, after proper training, dogs can also be used in mine detection. Dog-assisted landmine detection teams have long provided useful assistance in humanitarian demining. Mine detecting dogs are able to detect nearly $95 \%$ of mines and indicate their position under favorable weather and soil moisture conditions. ${ }^{13}$ Some research has shown that dogs are able to detect explosive odor molecules at concentrations lower than those measured by the best chemical sensors. However, this performance may vary depending on the particular dog, its level of training, and the characteristics of the area.

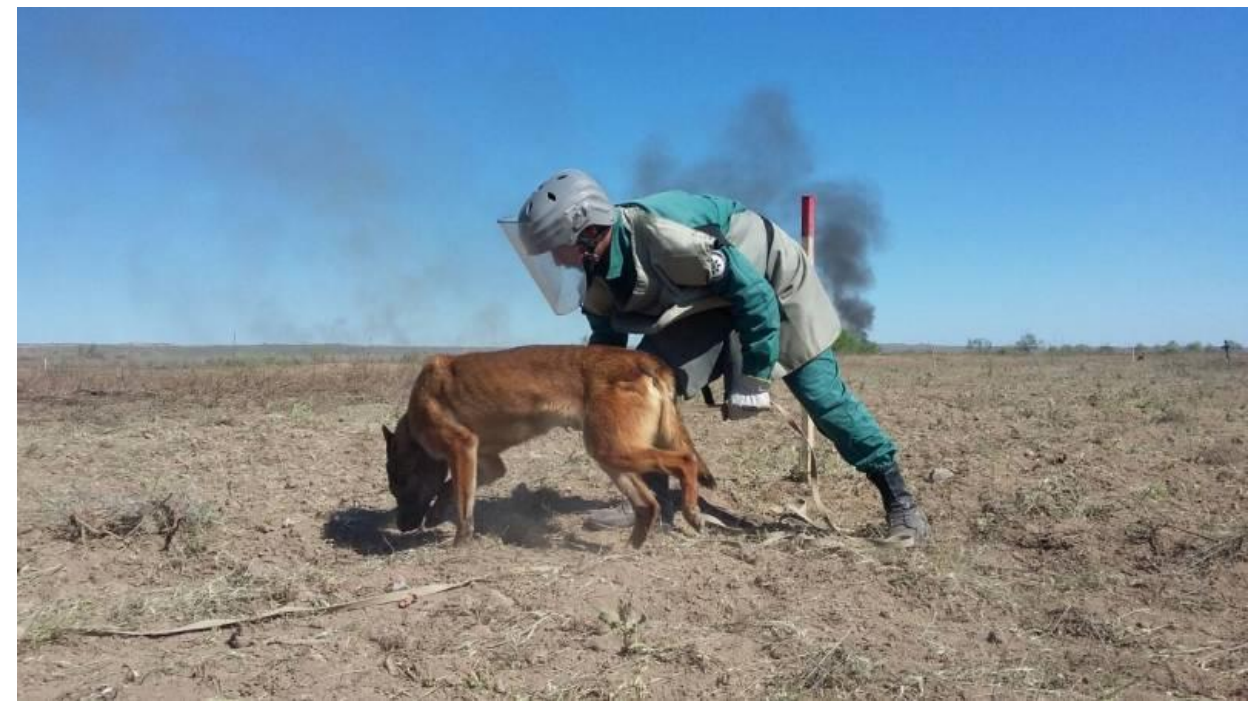

Figure 3.

A mine detection dog from the Marshall Legacy Institute, with his handler, helps to clear the land of Azerbaijan from mines

(Source: https://alex-news.ru/armija-159/amp/ Downloaded: 21. 08. 2020.)

The purpose of using a dog is to detect explosive devices located under the ground. During humanitarian demining, dogs detect and accurately mark the location of landmines in already known or suspected minefields and mine-contaminated

\footnotetext{
${ }^{12}$ Mine Detection Dogs 2003. p. 17.

${ }^{13}$ Macdonald et al. 2003. p. 68.
} 
areas. The manner of indication of a mine detecting dog is always a passive manner, which means that the dog sits down or lies down when the learned odor is detected and shows the exact location of the odor source with its nose. You must not touch or scratch the possible location of the landmine. The mine detecting dogs perform their duties under strict rules, within a defined area, usually in a $1 \mathrm{~m}$ bandwidth. In all cases on a leash.

During the dogs training, it is important for the dog to learn the limited activity between the range of motion delimited by the lane boundaries, as inappropriate behavior can cause an explosion that can lead to injury or even to the death of the dog and its handler.

Differently from humanitarian demining, in military practice a mine detection dog can also be used to detect vulnerable points and perform man rescue from a minefield. In some cases, mine detecting dogs can also be used to detect underground placed UXO and improvised explosive device (IED), but basically, other specially trained dogs should be used for these tasks. ${ }^{14}$

\section{Utilization of African giant rats}

Rats are known to have a good sense of smell, and even recent researches suggest that their sense of smell is three-dimensional. Just 50 milliseconds prove to be enough for them to determine the direction of the smell. ${ }^{15}$ In 1995 , while analyzing the landmine problem, the question arose: How intelligent rats, known for their good sense of smell and widespread throughout the world, could be trained to detect landmines?

In addition to the natural abilities of the animals that make them suitable for landmine detection tasks, another aspect must be met, they need to be able to work with people. During the period of human tribal development the rats did not develop in coevolution with humans like dogs, rats only use and adapt to human habitat, but develop independently from it. Despite all this, they showed a very good willingness to cooperate during the tests. The initial tests also confirmed the basic assumption that African giant rats learn quickly, are well conditioned, and the knowledge learned is sufficiently fixed to be applicable in the field.

The training of African giant rats is similar to the training of mine detecting dogs. The rats make a signal when they detect the odor, which in this case is an active manner of indication, they scratch the ground surface with their upper legs. They get rewarded for the accurate indication. Because unlike dogs, rats are not playful animals, so this reward is always food. The great advantage of using rats is that their body weight is very small, so that they do not activate the anti-personel landmines as a consequence of an accidental step. Giant rats can also be used effectively in heavily metal-contaminated areas, they look for explosive molecules in the air like

\footnotetext{
${ }^{14}$ Horváth 2019. p. 96.

${ }^{15}$ Bertus-Barcza 2006.
} 
dogs, while ignoring other odors and their activity is not affected by metal contamination. Based on all this, they serve as a perfect solution to speed up the search for mines, thus saving significant costs by employing African giant rats.

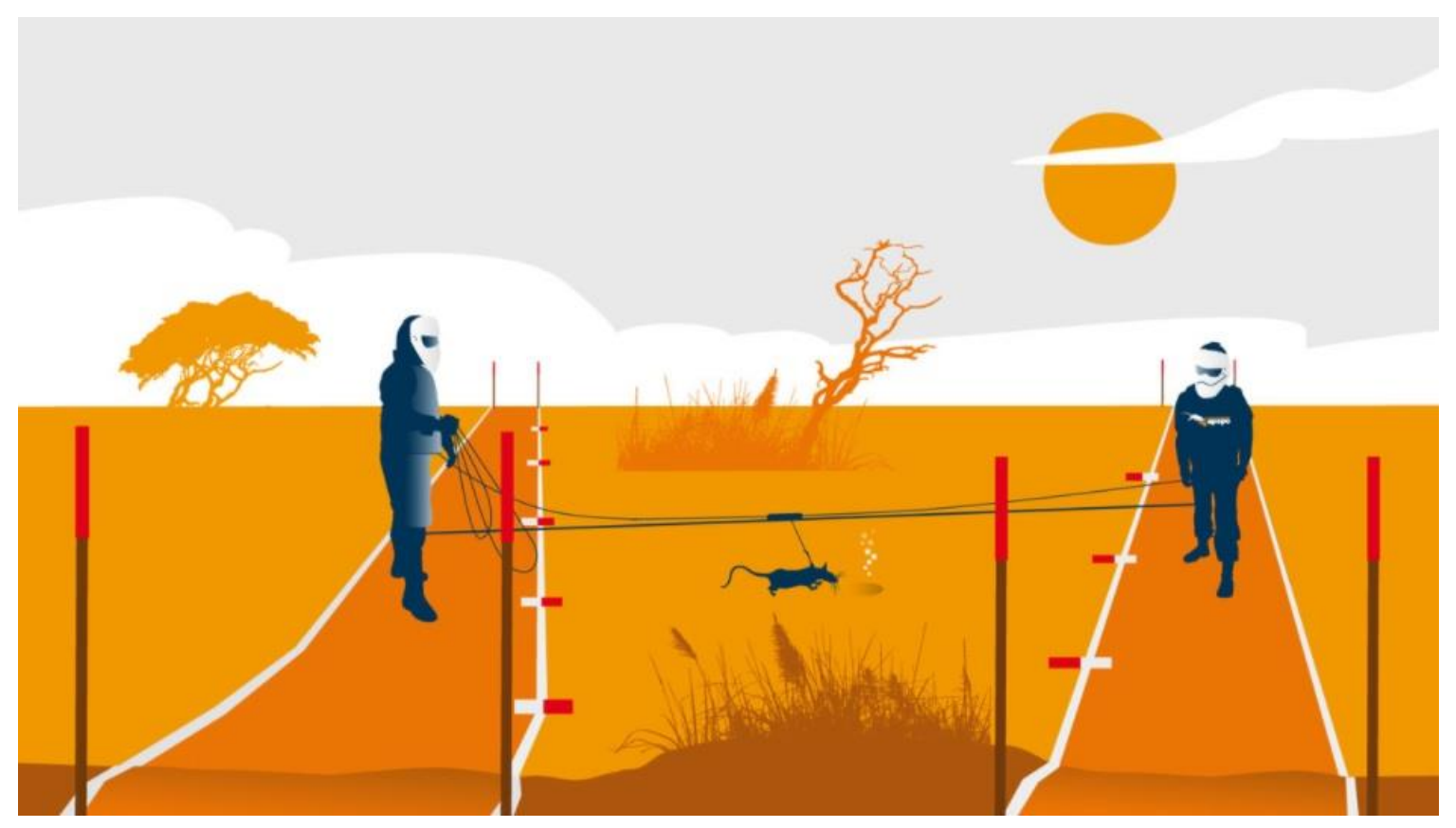

Figure 4.

Using african giant rats in landmine detection

(Source: https://www.apopo.org/en/what-we-do/detecting-landmines-and-explosives/how-we-doit/mine-clearance Downloaded: 07. 11. 2019.)

By comparison, a well trained African giant rat is able to search an area the size of a tennis court within 30 minutes, which requires a minimum of four days with any conventional hand-held demining metal detector. The program has been operating effectively in Tanzania and Angola, since 1997.

\section{Utilization of honey bees}

Unlike African giant rats, the use of honey bees does not require close cooperation with humans, it is based solely on monitoring their natural behavior. Scientists at the Los Alamos National Laboratory have developed a method for training honey bees that can be used effectively to detect explosives. The research was based on the previously known fact that the development and quality of the smell of honey bees are almost the same as that of dogs. Research has shown that bees can detect a concentration of 2,4 DNT of $10^{-12} \mathrm{~g} / \mathrm{ml}$. The sensitivity threshold for some explosive detection detectors is also calibrated to this level.

During their application, handlers use two main methods, the passive method and the active method. The passive method does not require special training of the bees, its essence is based on their natural behavior. Members of the honey bee colony make tens of thousands of feeding trips a day in an area of the order of $2 \mathrm{~km}^{2}$. 
During these feeding routes, insects come into direct contact with most environmental media (air, water, plants, and soil), and in the process, gaseous, liquid, and particulate contaminants get on their bodies. These contaminants are returned to the beehive and handlers take a sample from the beehive environment. The collected samples are analyzed in a laboratory. Tracking contaminants entering the beehive offers a quick, inexpensive way to assess chemical distribution and environmental impacts. However, with this method the exact location of an individual landmine or groups of mines in the area cannot be determined, only the degree of contamination of mines and explosives in the area can be determined.

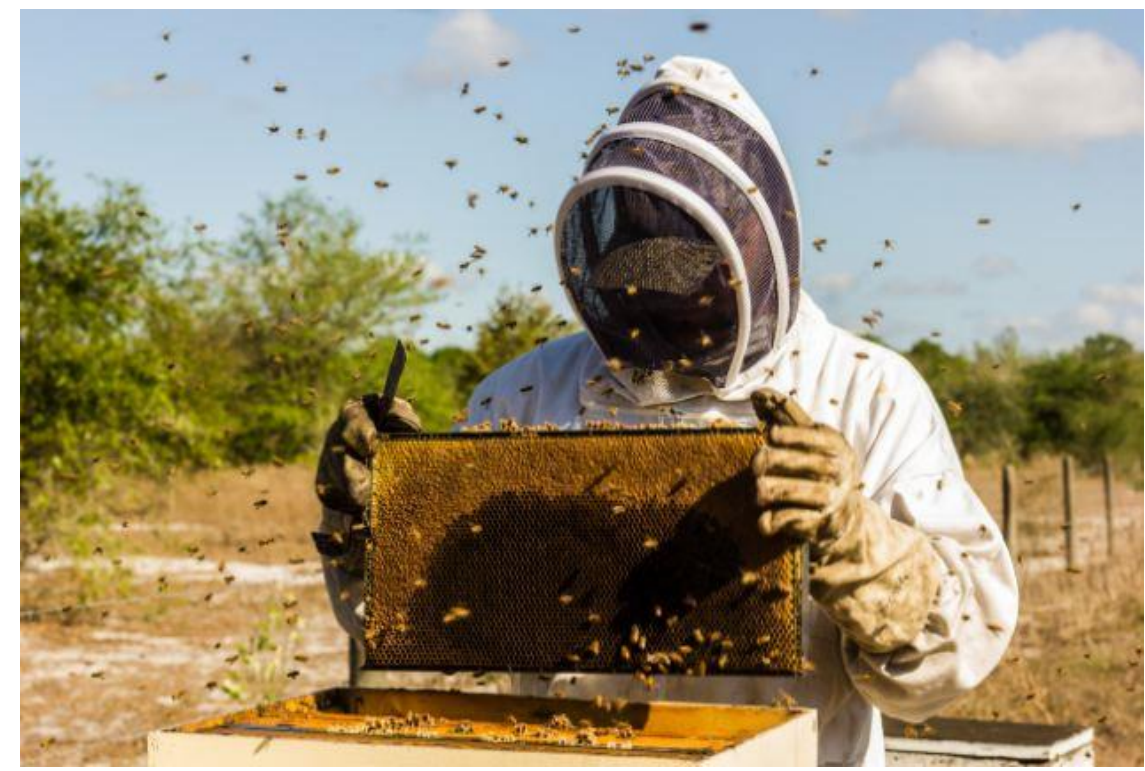

Figure 5.

Training of honey bees in Croatia

(Source: Prigg 2013.)

In contrast, the active method can already determine the exact location of the mines, however, such an application requires the training of bees. Honey bees are trained using standard Pavlovian ${ }^{16}$ training techniques in bee research.

The selected bees are housed in a tent where nitrate-based explosives are also placed. Due to the evaporation of the exploder, the explosive odor molecules are enriched in the tent. Meanwhile, food that is tempting for the honey bees is also placed in the tent, so that while the bees are feeding, they also constantly detect the smell of the explosive. During the process, the animals under training connect the food with the odorant. After their training application, bees consciously fly over the area to search for the learned odor and indicate its location by floating over a landmine, group of mines, or an area heavily contaminated with explosives. Given the ratio of the extent of the area to the body size of the honeybees, their observation with the naked eye is not possible at all or only possible in large numbers.

${ }^{16}$ Conditional reflex and classical conditioning discovered by russian physiologist Ivan Petrovich Pavlov. 
To solve this problem, high-resolution cameras are used, which are mounted on drones. The cameras can be used to track the movement of honey bees and determine with relative accuracy the area where an indication of the presence of an explosive has been made. The method is currently being tested in Croatia as well as in Bosnia and Herzegovina. The Biological Method (Bees) for Explosive Detection project is part of NATO's Science for Peace and Security Program. It began on November 3, 2017 and is scheduled to run for three years.

They are also working to develop new methods and tools for the optical detection of bees in complex environments. One such method is based on the fact that light scattered from the wings of bees moving over an explosive-contaminated area provides an intensity-modulated signal, typically at a wing speed of $170-270 \mathrm{~Hz}$, the detection of this range can be used to determine the position of honey bees. ${ }^{17}$ Optical detection of honey bee markings in this direction can more accurately determine the location of landmines and areas contaminated with other explosive devices. Further studies are also underway on the ability of honey bees to detect explosives in the presence of interfering chemical odors such as motor oil or insect repellents. The research is coordinated by the Defence Advanced Research Projects Agency (DARPA). In order to test the applicability of the ability in the real field, it is necessary to put the methods successfully used in laboratories into practice. The "Biological Method (Bees) for Explosive Detection" project aims to develop innovative methods and technologies for the detection of landmines located below ground level. Within the framework of the program, they try to achieve a specific goal by developing and integrating trained honey bee colonies. The advantage of using trained bees is that they detect evaporated explosives, so they can be used well in heavily metalcontaminated areas. The methods can be used to clarify the assumed mined area and to confirm the completion of demining during internal and external quality control.

\section{Utilization of marine mammals}

Researchers have been impressed for decades by the ability of marine mammals to obtain high-resolution information about their habitat. Seeing these capabilities, the question arose: How they could be used to detect marine mines? The U.S. Navy has been experimenting with bottlenose dolphins for mine detection for more than 50 years, in order to teach them how to search for and mark explosive devices in the water. Most of the dolphins were bred by the Navy in San Diego, but some were caught in the wild in the $1980 \mathrm{~s} .{ }^{18}$ Initially, cameras were placed on the dolphins. With

\footnotetext{
${ }^{17}$ Optical detection of honey bees by use of wing-beat modulation of scattered laser light for locating explosives and land mines. https://www.researchgate.net/publication/7206133 Optical detection of honeybees by use of wing -beat modulation of scattered laser light for locating explosives and land mines (Downloaded: 22. 07. 2020.)

18. The Story of Navy dolphins,
https://www.pbs.org/wgbh/pages/frontline/shows/whales/etc/navycron.html, (Downloaded: 17.05. 2020.)
} 
the dolphins' cameras, the researchers were able to get to know the animals' behavior better, as they could hear their voices during the task and follow their behavioral changes when the mine was detected. ${ }^{19}$ Nowadays, the availability of increasingly up-to-date hardwares and softwares for the processing of information, provide an opportunity for understanding the constant knowledge and the abilities of animals, and provide for those skilled in the art to make significant advances in this field of science and technology. ${ }^{20}$

The watermine manufacturers use a variety of methods to reduce the detectability of mines. For example, materials and shapes that fit better into the environment are used, as well as antimagnetic materials or shapes with a low acoustic cross-section, making it increasingly difficult to detect mines using conventional mine detection sonars. This forced the Navy to develop new mine detection systems. A new solution is to learn about and apply biological sonar to marine mammals. These marine mammals are able to detect prey with sonar, even very small fishes - which are significantly smaller than any known mine - that hide in the sediment of the seabed. The ability of bottlenose dolphins surpasses state of the art technology in many ways. They are effective in locating and marking mines. Thanks to their natural sonar system, dolphins can easily find explosive devices in the water and then mark them with the help of a buoy, so that naval ships can avoid them, or be neutralized by naval explosive ordnance disposal (EOD) divers.

Mine detecting bottlenose dolphins were deployed in the Persian Gulf during the 2003 Iraq war. The Navy says these dolphins are effective in detecting more than 100 underwater mines and other improvised explosive devices. ${ }^{21}$ The U. S. Navy has basically trained three groups of dolphins to detect watermines that pose a serious threat to warships. The dolphins in the first group were used to locate and mark the location of floating mines, that were fixed to the seabed. The dolphins in the second group were trained to detect and mark the location of mines buried in sediment of the seabed, while the third group was tasked with locating safe corridors needed to transport troops ashore. These animals are able to find objects even in poorly visible conditions where divers do not see anything. The researchers observed that dolphins change their behavior when they detect mines and change the type, duration, and frequency of the sound pulse they emit. ${ }^{22}$

\footnotetext{
${ }^{19}$ Ridgway et al. 2018. p. 1.

${ }^{20}$ Naval Mine Warfare 2001. p. 95.

${ }^{21}$ Pickrell 2003.

22 Undersea Warfare 1997. p. 72.
} 

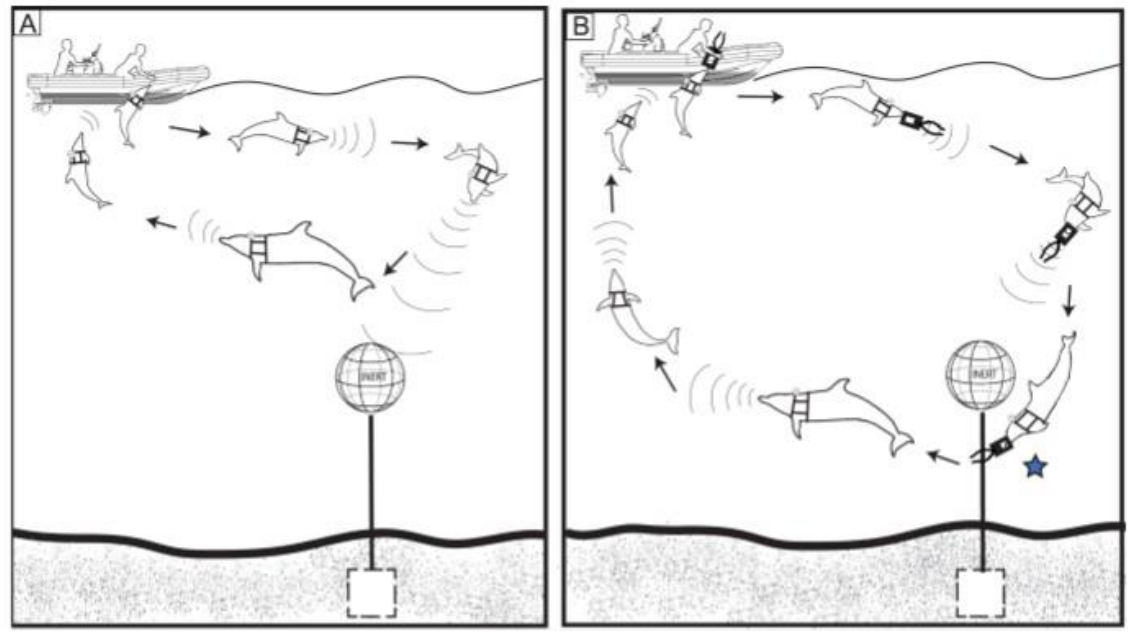

Figure 6.

Sketch of bottlenose dolphin behavior during underwater mine detection (A) and underwater mine marking (B)

(Source: Ridgway et al. 2018. p. 4.)

With the help of modern technical devices placed on the escorting ships, the changes in the behavior of the dolphins can be detected from a greater distance. Dolphins can be tracked even, and the location of the sound pulse change can be precisely determined. It can be determined, that the proper integration of biological sonar systems and technical devices, compared to previously used procedures, will allow more efficient mine detection under the water.

\section{Influencing factors of animal-supported mine detection}

If we want to examine the real applications of animal-supported mine detection, it must be born in mind that there are limitations and obstacles to their use. After all, a living organism is not an automatic system, so environmental conditions and other impacts affect and influence its performance.

Climatic conditions influence the ability of animals to work, affect the duration of their applicability and in extreme cases, they also affect its effectiveness. Some mammals cool their bodies by panting at high outside temperatures, it follows that, due to the required evaporation, their efficiency during mine detection decreases under such conditions. Not only extremely hot, but also extremely cold weather can affect the performance of animals and their use in such conditions, therefore it requires increased attention. The average body temperature of a dog and a rat is higher than that of a human. Nonetheless, it should be protected from the effects of the cold. 


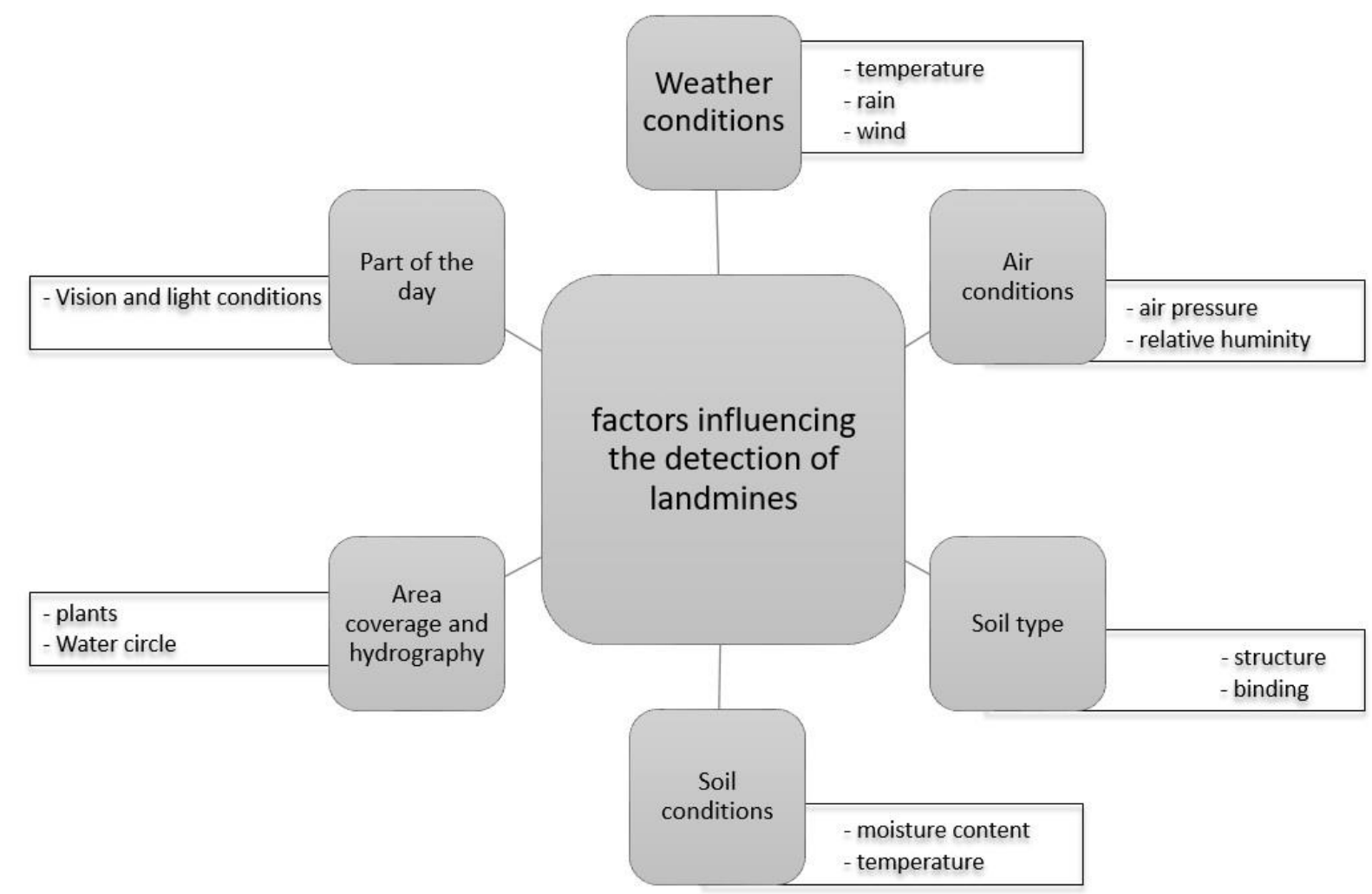

Figure 7.

Influencing factors of landmine detection

(Source: Created by the author)

Mine detecting dogs are able to perform their duties in cold weather with due care. There is no experience with the use of African giant rats in cold weather, because they have only been used in Tanzania and Angola until now. However, given that the ideal ambient temperature for these animals is above $20{ }^{\circ} \mathrm{C}$, their use in cold weather is likely to be limited. Honey bees are also limitedly used in cold weather, because honey bees do not fly at all below $5{ }^{\circ} \mathrm{C}$. In addition, tests with honey bees have been conducted in open fields so far, so their true performance in a heavily vegetated environment is unknown. Presumably, tracking the movement of honeybees in a heavily vegetated environment would also cause difficulties.

In the case of terrestrial animals, the direction and strength of the wind affect the activity, making it difficult to recognise the location of the mines accurately, or not allowing their use at all. Extreme weather conditions affect not only the animals' bodies but also affect the environment of application and the explosives, too. In hot weather conditions, the explosive in the mine evaporates more intensively so that the odor molecules of the explosive can quickly enrich within a given area, which can also make it difficult to recognise their location.

In extremely cold weather conditions, the reverse is true, meaning that the explosive evaporates less, so fewer odor molecules are released into the air within a given area, which can also make detection difficult. 
Mine detecting dogs and rats may also experience olfactory exhaustion. The application, which is often carried out under difficult conditions and with physiologically strong odors, uses not only the olfactory organ of the animal but also its entire body. ${ }^{23}$ Under these circumstances, performing a detection requires a high degree nerve focus from the animals, which can increase its physical and sensory fatigue. As a result, the animal may become insecure or its motivation may decrease.

Mine detection in the case of soil can be affected by three factors. The composition of the soil is determinative, as TNT and DNT molecules reach the soil surface more slowly in denser structured soils, than in loose sandy soils due to sorption. Soil temperature can also affect landmine detection, because in case of cold soil temperature, less steam is formed on the soil surface.

Soil moisture content affects the concentration of TNT and DNT in the air layer above landmines. In the case of dry soils, the sorption is high therefore the concentration decreases. When the soil becomes moist, water displaces TNT and DNT molecules from their direct soil surface, so they are absorbed in the air layer, resulting in much higher concentrations. However, in the case of continuous wetting for example in the event of prolonged rain- the water has the opposite effect and washes off the explosive molecules from the soil surface, as a result of which, the concentration significantly decreases. ${ }^{24}$

The edging, coverage and walkability of the terrain also have an impact on the effective use of mine detecting animals. These may include terrain that is impassable and insurmountable to the animal, as well as objects that cause physical damage to the soil surface (e.g., sharp crushed stone or large amounts of shattered glass). If the factors influencing the use of the animals cannot be eliminated, the landmine detection should be scheduled at a different time or, if that is not possible, the detection must be carried out by other methods.

\section{Summary, conclusions}

The study shows that the service of animals can also play a significant role in the performance of the tasks of a modern-day soldier, which is widely supported by technical means, and their abilities provide us with many applications both on land and underwater. It can be stated that the use of the service of the animals still has a place and a role in the conduction of military operations today. Mine detection is an extremely costly, time consuming and high risk activity. Thus, it is unequivocal that in addition to advanced techniques and procedures, the application of biological methods also comes to the fore.

New procedures based on innovative technologies for the detection of mines and other explosive remnants of war in mine-contaminated areas are an extremely promising approach. Biological detection technology has the potential to compete

\footnotetext{
${ }^{23}$ Horkay 2012. p. 14.

${ }^{24}$ Mine Detection Dogs 2003. p. 201.
} 
with or be used in conjunction with modern technology to enable more efficient detection. After all, it is currently very difficult or impossible to achieve the capabilities of animals with artificially produced technical devices.

Understanding biological systems and the possible integration of living and nonliving components offer unique opportunities to develop mine detection capabilities. The conscious use of the abilities of animals in this direction, may become a prominent method of detection techniques in the fight against landmines and underwater mines.

\section{REFERENCES}

Bálint Péter: Orvosi élettan. Budapest, Medicina könyvkiadó, 1986.

Existing and Potential Standoff Explosives Detection Techniques. Washington, The National Academies Press, 2004.

Fehér György: A háziállatok funkcionális anatómiája. Budapest, Mezőgazdasági Kiadó, 1980.

Horkay Béla: A kutya egészségtana. Kísérleti jegyzet a robbanóanyag-kereső kutyavezetők kiképzéséhez, 2012.

Horváth Tibor: Magyarország akna- és lőszermentesítésének története. A kezdetek 1944-1948. Müszaki Katonai Közlöny, 28. ( 2018/1). pp. 68-75.

Horváth Tibor: Emergency cases at countering improvised explosive devices, and their potential management. Revista Academiei Fortelor Terestre / Land Forces Academy Review, XXIV., No 2., 2019. pp. 95-106.

Landmine Monitor Report: 21st Annual Edition, International Campain to Ban Landmines- Cluster Munition Coalition (ICBL-CMC). 2019.

Macdonald, Jacqueline et. al.: Alternatives for Landmine Detection, RAND's Publications, Santa Monica, 2003.

Miklósi Ádám: A kutya viselkedése, evolúciója és kogníciója. Budapest, Typotex, 2010.

Mine Detection Dogs: Training, Operations and Odour Detection, Geneva, Geneva International Centre for Humanitarian Demining (GICHD), 2003.

Naval Mine Warfare: Operational and Technical Challenges for Naval Forces, Washington, The National Academies Press, 2010.

Pickrell, John: Dolphins deployed as undersea agents in Iraq. National Geographic News, 2003.

Ridgway, Sam H. - Dlbble, Dianna S. - KennemE, Jaime A. R: Timing and context of dolphin clicks during and after mine simulator detection and marking in the open ocean, Cambridge, The Company of Biologists, 2018. 
Szatai Zsolt József: Aknák, aknamezők felderítési lehetőségei. Müszaki Katonai Közlöny, 29. ( 2019/4), pp. 43-63.

Undersea Warfare. Washington, The National Academies Press, 1997.

Vroon, P.- van Amerongen, A.- de V , H.: A rejtett csábító, a szaglás pszichológiája. Budapest, Korona kiadó, 2005.

\section{INTERNET REFERENCES}

Bertus-Barcza Péter: A patkányok kifinomult orra térhatású szaglást tesz lehetővé. Available:https://ng.hu/termeszet/2006/02/03/a patkanyok kifinomult orra terha tasu szaglast tesz lehetove/)

Detecting Explosives With Honeybees: Experts Develop Method To Train Air Force Of Bomb-sniffing Bees.

Available:https://www.sciencedaily.com/releases/2006/11/061128140820.htm

A mine detection dog from the Marshall Legacy Institute, with his handler, helps to clear the land of Azerbaijan from mines. (Собака минно-розыскной службы из Marshall Legacy Institute вместе со своим вожатым помогает очищать землю Азербайджана от мин.) Available: https://alex-news.ru/armija-159/amp/

Prigg, Mark: The Croatian 'bomb bees' that can sniff out landmines from THREE MILES away. Available: https://www.dailymail.co.uk/sciencetech/article2315198/The-bomb-bees-sniff-landmines-THREE-MILES-away.html

Optical detection of honeybees by use of wing-beat modulation of scattered laser light for locating explosives and land mines. Available:

https://www.researchgate.net/publication/7206133 Optical detection of honeyb ees by use of wing-

beat modulation of scattered laser light for locating explosives and land $\mathrm{mi}$ nes

The Story of Navy dolphins.

Available:https://www.pbs.org/wgbh/pages/frontline/shows/whales/etc/navycron. $\underline{\text { html }}$

Using african giant rats in landmine detection. Available:

https://www.apopo.org/en/what-we-do/detecting-landmines-and-explosives/howwe-do-it/mine-clearance 